\title{
Nutrient dynamics in a tropical estuary: a microcosm approach
}

\author{
MARIA APARECIDA MACEDO DA SILVA ${ }^{1 *}$, Eline NAYARA DANTAS DA COSTA ${ }^{1}$, \\ MARCELO FriederichS LANDIM SOUZA ${ }^{1} \&$ PAUlo CESAR OliVEIRA VERgNe ABReU ${ }^{2}$ \\ ${ }^{1}$ Universidade Estadual de Santa Cruz - UESC, Laboratório de Biogeoquímica Marinha, Rod. Ilhéus- \\ Itabuna km 16, 45650-000, Ilhéus, BA, Brasil \\ ${ }^{2}$ Universidade Federal do Rio Grande FURG- Programa de Pós-Graduação em Oceanografia Biológica, \\ Laboratório de Fitoplâncton e Microorganismos, Av. Itália, Km 08, 96201-900, Rio Grande, RS, Brasil.
}

*Corresponding author: cidahmacedo@yahoo.com

\begin{abstract}
Understanding material input changes within estuarine environments is essential to assess nutrient exportation to nearshore coastal waters and their influence on coastal and oceanic region ecology. This study is aimed at describing the nutrient and phytoplanktonic biomass dynamics in a tropical estuary, affected by sewage and agricultural run-off, through a microcosm experiment. Dissolved organic and inorganic N (DON and DIN), and P (DOP and DIP), chlorophyll-a and silicate were measured during dry and rainy periods to compare the inner and outer portions of the Cachoeira River estuary. In the inner portion at the beginning of the experiment, $\mathrm{NH}_{3}{ }^{+} \mathrm{NH}_{4}{ }^{+}$, DOP, $\mathrm{SiO}_{4}{ }^{-4}$ and $\mathrm{PO}_{4}{ }^{3}$ concentrations were highest during the rainy period, while, the highest values of chlorophyll-a and DON occurred in the dry period. The nutrient assimilation by phytoplankton was responsible for $\mathrm{N}$-ammoniacal, nitrate and phosphate decrease. Nitrate was the greatest source of nitrogen and was totally depleted into the incubation days. Nitrification occurred, but possibly was not the most relevant mechanism in removal of $\mathrm{NH}_{3}{ }^{+} \mathrm{NH}_{4}{ }^{+}$. DON and DOP were probably used by phytoplankton. The highest nutrients concentrations in the inner portion confirmed the influence of sewage discharge nutrient dynamics and a water renewal in the outer portion indicated by previous studies in the Cachoeira River estuary.
\end{abstract}

Key words: experiment, chlorophyll-a, nitrogen, phosphorus.

Resumo: Dinâmica de nutrientes em um estuário tropical: uma abordagem com microcosmo. Compreender mudanças na entrada de material em estuários é essencial para avaliar a exportação de nutrientes em águas costeiras e sua influência na ecologia da região oceânica. Este estudo teve como objetivo descrever a dinâmica da biomassa fitoplanctônica e de nutrientes em estuário tropical afetado por escoamento agrícola e esgoto por meio de experimento com microcosmos. Foram medidos nitrogênio e fósforo orgânicos e inorgânicos dissolvidos (NOD, NID, POD e PID, respectivamente), clorofila-a e silicato, comparando as porções interna e externa do estuário do Rio Cachoeira, nos períodos seco e chuvoso. Na porção interna, principalmente no início do experiment, as concentrações de NID, POD, $\mathrm{SiO}_{4}{ }^{-4}$ e $\mathrm{PO}_{4}{ }^{3}$ foram maiores durante o período chuvoso e os maiores valores de clorofila-a e NOD ocorreram no período seco. A assimilação dos nutrientes pelo fitoplâncton foi responsável pela diminuição do $\mathrm{N}$-amoniacal, nitrato e fosfato. O nitrato foi a maior fonte de nitrogênio sendo consumido durante a incubação. A nitrificação ocorreu, mas possivelmente não foi o principal mecanismo na remoção do $\mathrm{NH}_{3}{ }^{+} \mathrm{NH}_{4}{ }^{+}$, o NOD e o POD provavelmente foram utilizados pelo fitoplâncton. Os padrões encontrados na porção interna confirmaram a influência do lançamento de esgoto para a dinâmica de nutrientes já apontada em estudos anteriores no estuário estudado. 
Palavras-chave: experimento, clorofila-a, nitrogênio, fósforo.

\section{Introduction}

Tropical estuaries are one of the most valuable and productive ecosystems on Earth, providing several physical, chemical, geomorphologic, environmental, and habitats such as mangrove forests and seagrass beds (McLusky \& Elliot 2004, Carvalho \& Fidélis 2013). These ecosystems provide many environmental services, but are responding to the many anthropogenic pressures that occur within their watersheds. Those pressures include population growth, urbanization, industry, and agriculture (Zapata et al. 2018). Land activities affect the runoff and may provoke an increase of pollutant and nutrient loading into coastal waters that promote the removal, alteration, or destruction of natural habitat (Vitousek et al. 1997, Syvitski et al. 2005, Halpern et al. 2008).

In coastal estuarine ecosystems surrounded by large human populations, biological assimilation, and regeneration of nutrients are commonly altered by anthropogenic activities. The understanding of the changes within the estuarine environment is essential to assess the export of nutrients to nearshore coastal waters and how they influence the ecology of coastal and oceanic regions (Davies \& Eyre 2005). The most significant anthropogenic impacts on estuarine ecosystems are the high load of nitrogen and phosphorus from domestic and industrial effluents that results in a process known as "anthropogenic eutrophication" (Nixon 1995, Smith et al. 1999, Pinckney et al. 2001, Rabalais 2002, Turner et al. 2003). In estuaries, the recycling of organic matter, nutrient adsorption/desorption, and sedimentation are relevant biological processes that affect the dynamics of nutrients such as nitrogen and phosphorus (McKee et al. 2000, Fukushima et al. 2001, Davies \& Eyre 2005).

Brazilian estuaries and coastal waters are subject to intensive anthropogenic eutrophication that is common in urban areas where municipal sewage collection and treatment systems are often inadequate or even nonexistent (Marques et al. 2004). In this case, the Cachoeira River estuary is a typical tropical estuary dominated by mangroves, located on the Eastern Brazilian Coast (Silva et al. 2015), that faces anthropogenic eutrophication. Several anthropic activities have developed along the Cachoeira River hydrographic basin, which contribute to increasing concentrations of $\mathrm{N}$ and $\mathrm{P}$ in many forms (Souza 2005, Souza et al. 2009, Lima et al. 2010, Lucio et al. 2012, Silva et al. 2013, Silva et al. 2015, Santos et al. 2018). The activities include pasture, agriculture, cacao crop cultivation as an agroforest system, and wastewater release of untreated domestic and industrial effluents in the riverbed (Cerqueira et al. 2020).

Previous studies in the Cachoeira River estuary revelated that the inner portion can be ranked as hypereutrophic, while the outer portion is mesotrophic (Souza 2005, Souza et al. 2009, Silva et al. 2013). It is hypothesized that the differences between the inner and outer estuary are probably a consequence of the direct input of anthropogenic nutrients in the inner portion. Beyond that, it is related to the geomorphologic characteristics and higher hydrodynamics of the outer estuary, which promotes greater water renewal and dilution in the outer estuary. These studies also described high concentrations of nutrients and phytoplankton biomass, especially in the inner portion of the estuary. In addition to dilution, the high phytoplankton biomass observed indicates that phytoplankton plays a key role in nutrient uptake and removal in Cachoeira River estuary.

To elucidate the relation between dynamics and the phytoplanktonic biomass behavior, the DON, DIN, DOP, phosphate and silicate were measured through a microcosm experiment, comparing sections from inner and outer Cachoeira River estuary portions during the rainy and dry periods. Thus, our objectives were (I) to observe the variations in phytoplanktonic biomass (Chlorophylla-a), DON, DIN, DOP, phosphate and silicate concentrations (II) to describe the mechanisms to the $\mathrm{N}$-ammoniacal removal (III) and to compare the results by the inner and outer estuary portions during dry and rainy periods. Phytoplanktonic biomass was represented by Chlorophyll-a concentration.

\section{Material and Methods}

Study Area: The drainage basin of the Cachoeira River is approximately 4,600 $\mathrm{km}^{2}$ (Melo et al. 2014) (Fig. 1). The total population in the basin is around 600,000 inhabitants and is located close to the coast. The main land use in the basin is $80.1 \%$ pasture, with cacao crop cultivation constituting $11.7 \%$ of the area, $3.9 \%$ is secondary forest and urban systems corresponding to $4.3 \%$. The city of Itabuna represents $69 \%$ of the total urban area with around 214,000 inhabitants (Cerqueira et al. 2020; IBGE 2020). The climate is humid tropical, with average 


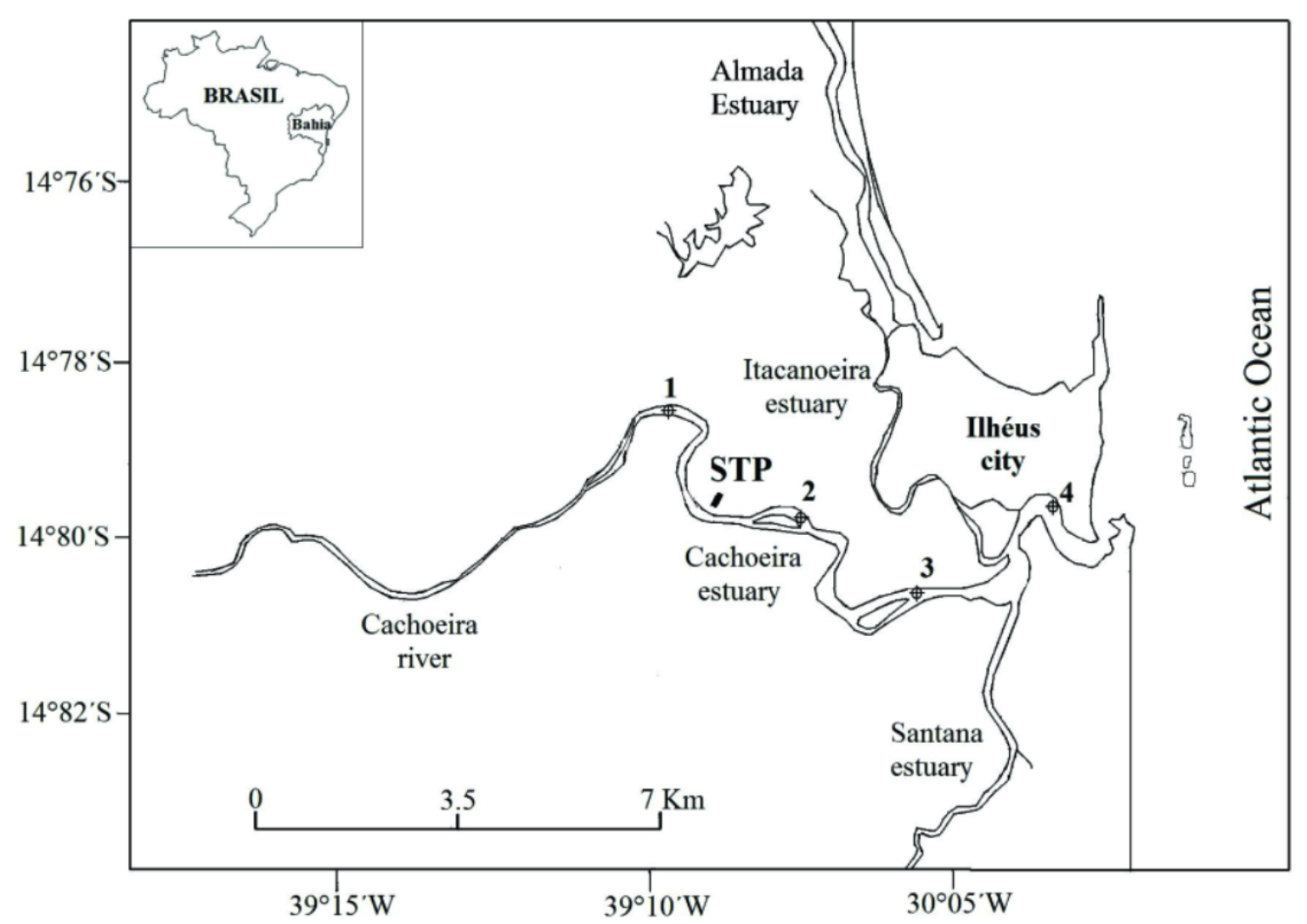

Figure 1. Map of the study area showing the location of sampling stations in the Cachoeira River Estuary. Stations 1 and $2=$ corresponding to the inner estuary portion; Stations 3 and $4=$ corresponding to the outer estuary portion. STP = sewage treatment plant

annual temperature of $24.6^{\circ} \mathrm{C}$ and rainfall between 1,500 and 2,000 mm (Klumpp et al. 2002). The rain and fluvial discharge are characterized by extreme irregularities, thus the annual average fluvial discharge is $24.1 \mathrm{~m}^{3} \mathrm{~s}^{-1}$, with historical records showing values between 0.2 and $1,460 \mathrm{~m}^{3} \mathrm{~s}^{-1}$ (Bahia 2001). This estuary is approximately $16 \mathrm{~km}^{2}$ surrounded by a mangrove area of $13 \mathrm{~km}^{2}$ and has a system of semi-diurnal tide with a height of approximately $2 \mathrm{~m}$.

The Cachoeira River estuary behavior during the high and low river flow period was studied by Souza (2005), Souza et al. (2009), Silva et al. (2013) and Silva et al. (2015). These studies have shown that the salinity increases with the tide as the main hydrological force. At the boundary between these two sections, there is a sandbar, which during the low flow, blocks the passage of seawater, thus hampering water exchange with the inner portion. Under these conditions, a long residence time of water is observed in the inner portion of the estuary. In this area of the estuary, saline stratification commonly occurs during the dry period and early rains. The outer portion of the estuary is predominantly well mixed and has a great water exchange with the sea.

Experimental design: Despite the rainfall being well distributed throughout the year in the estuary area, it is possible to highlight that month with high and low rainfall volumes as April and August, respectively. The months for data collection were chosen from the observations of the monthly average and total rainfall over the last 12 years presented by the Weather Monitoring Program in Real Time PROCLIMA (Figs. 1, 2; Table SI).

To define dry and rainy periods in this study, the sampling months were chosen considering the weekly total precipitation values and the discharge. Thus, the data collection was carried out on August 18th of 2009, it was defined as the dry period with weekly total precipitation of $17,24 \mathrm{~mm}$ (Fig. 3) with

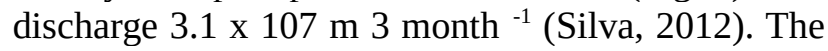
second data collection was carried out on April 15th of 2010 and it was defined as a rainy period with weekly total precipitation of 72,17 mm (Fig. 3) with

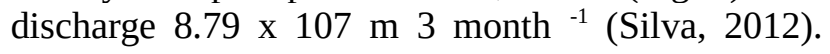
According to the McLusky \& Elliott (2004) 


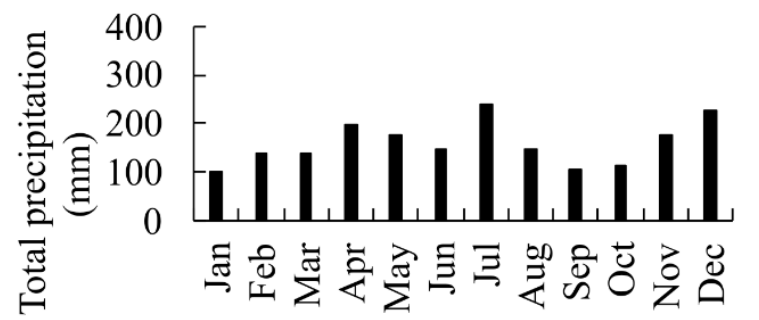

1999
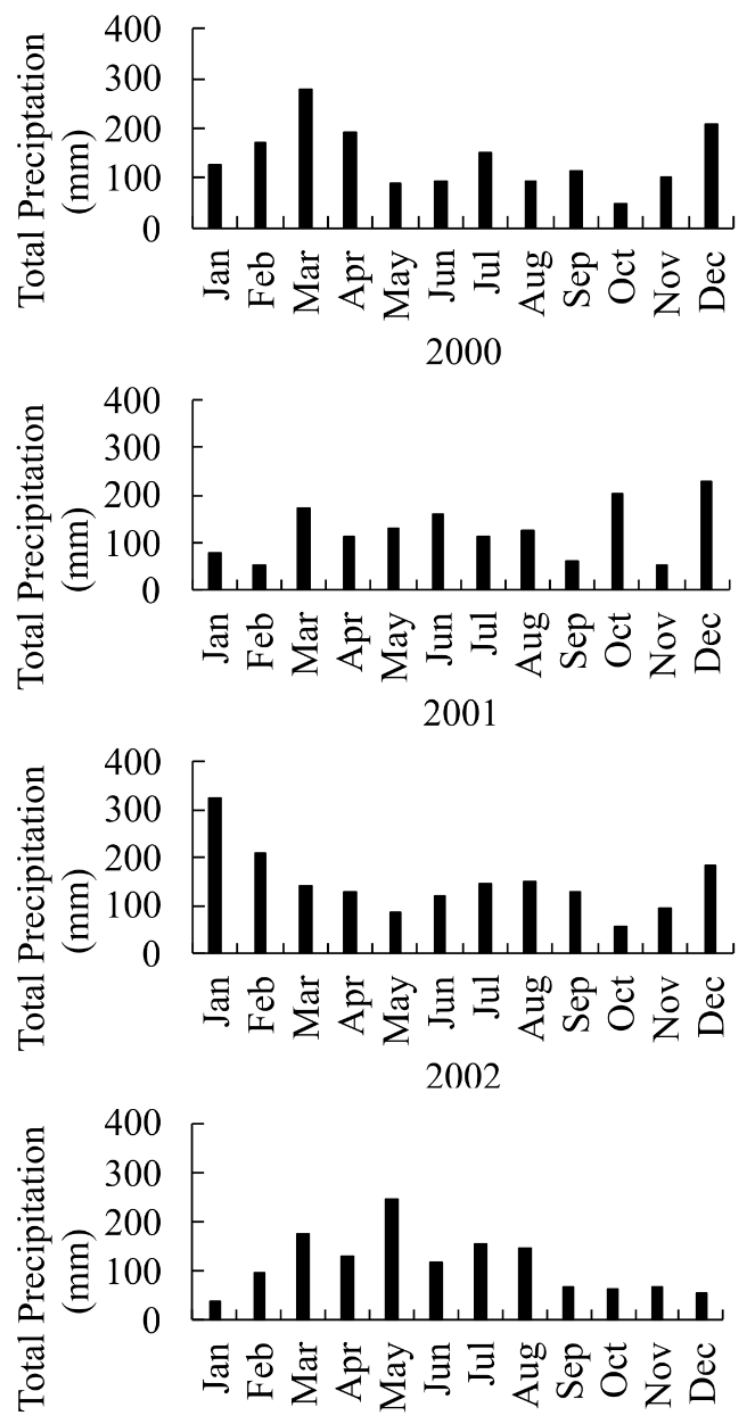
2003

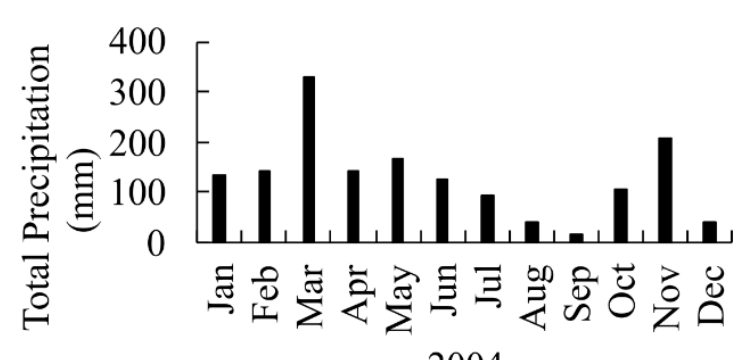

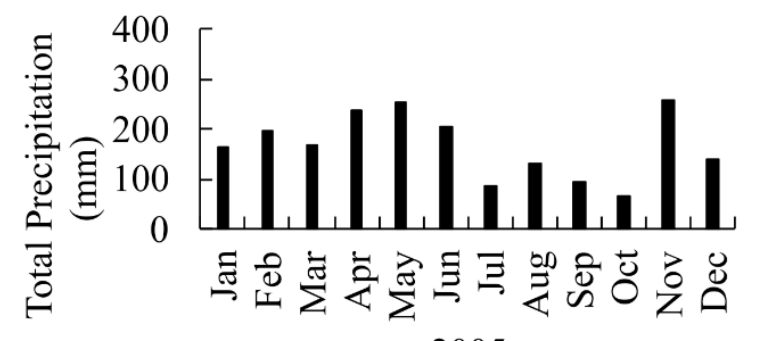

2005
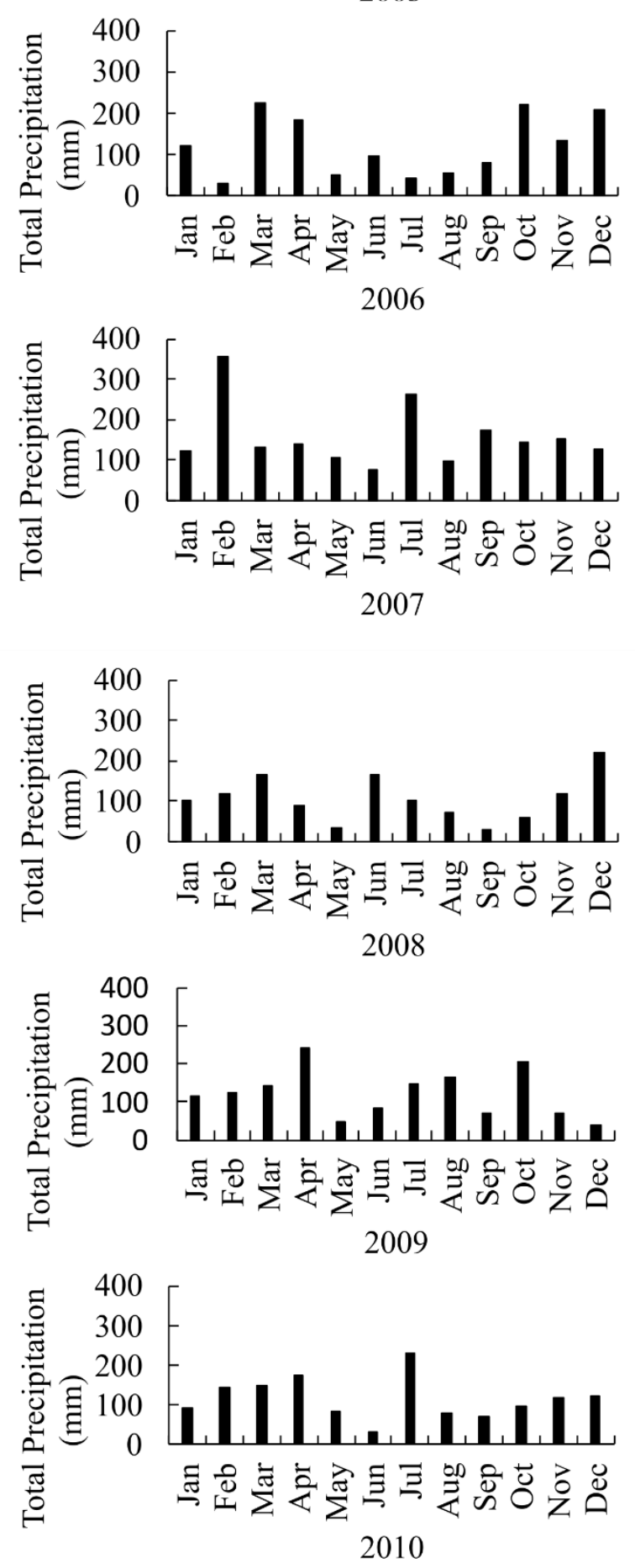

Figure 2. Monthly total precipitation (mm) from 1999 to 2010 in the Cachoeira River Estuary by Weather Monitoring (PROCLIMA). 


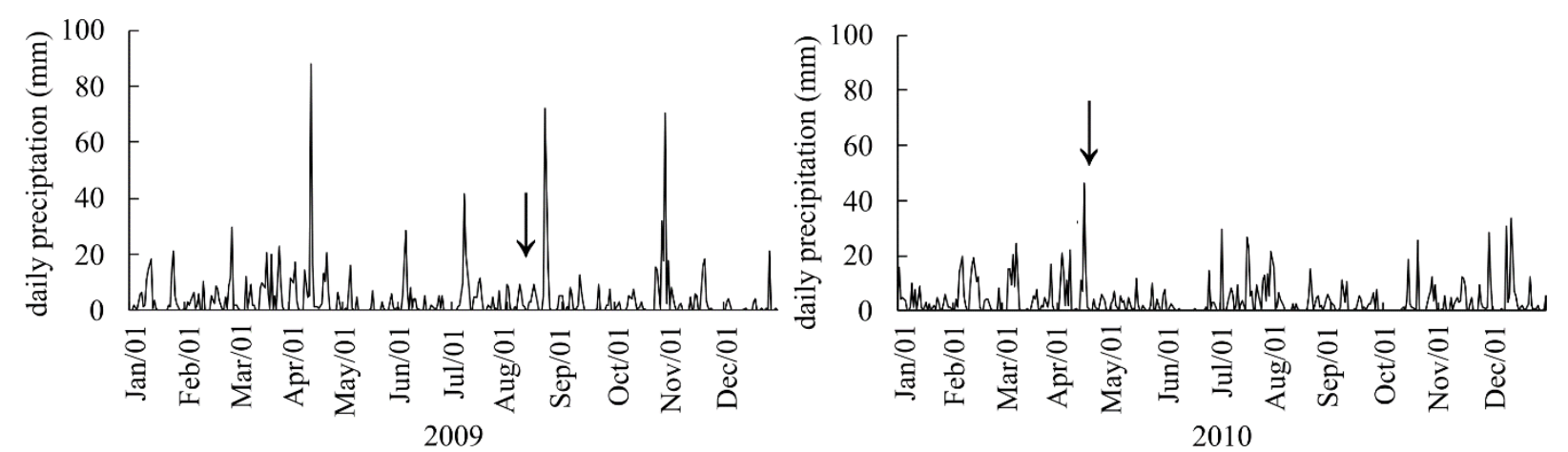

Figure 3. Daily precipitation (mm) from 2009 to 2010 in the Cachoeira River Estuary by Weather Monitoring Program in Real Time (PROCLIMA). Arrow is indicating the data collection day.

classification, the Cachoeira River estuary varies at the beginning of the rainy period from positive well stratified to partially stratified (Souza, 2005). However, at the dry period, it can be negative (or inverse; Guimarães, 2006).

Surface water samples (60 L) were collected in triplicate at four stations located along the salinity gradient in the Cachoeira River estuary (Fig. 1). Station 1 was located upstream of the sewage treatment plant (STP) and the station 2 immediately downstream, both stations in the inner estuary portion. Stations 3 and 4 were located in the outer portion of the estuary (Fig. 1). The triplicate water samples from each station were collected during the dry and rainy periods and transferred to a protected area located in the Ilhéus City Harbor to perform the microcosm system (Fig. 4). The microcosm system was used to analyze the processes related to the removal of nutrients by phytoplanktonic assimilation observed by the relations between the Chlorophyll-a concentration, silicate, phosphate and DON, DIN and DOP.

Microcosm system and sampling: The microcosm experimental system consists of a structure of iron bars, polyethylene foam tubes, and clear plastic bags with a capacity of $60 \mathrm{~L}$ floating in a harbor protected area (Fig. 4). The distance between the lower part (polyethylene floating foam) and the "mouth" of the microcosm was designed to prevent water from entering the microcosm environment. In addition, there was an umbrella-cover type made of transparent plastic to prevent the entry of rainwater in the microcosms and allowing the passage of light. The microcosms were assembled and lined up in the surface of water with the aid of ropes, totaling 12 experimental units (triplicate of the four sampling stations). The distances between microcosms were defined at approximately $1 \mathrm{~m}$ to prevent shadowing (Fig. 4).

To compose the microcosm experiment, $60 \mathrm{~L}$ triplicate water samples were collected from the stations (1,2,3, and 4) during the dry and rainy periods and transported with a polyethylene bucket (on the same day) to the microcosm experiment deployed at the Ilhéus City Harbor. These water sample collections from stations were performed in one day for each period. All of the polyethylene bottles were previously washed with $\mathrm{HCl} 1: 1$ and distilled water. In each sampling station the water temperature, $\mathrm{pH}$, and dissolved oxygen were measured in situ.

The microcosms experiments lasted 15 days for each dry and rainy period. The experiment was carried out by collecting $1 \mathrm{~L}$ water aliquot every two days in each microcosm at around 9:00 AM using a beaker. The aliquots were transferred into polyethylene bottles previously washed with $\mathrm{HCl}$ 1:1 and distilled water. The aliquots were kept under refrigeration during transportation for analysis at the laboratory.

Every two days the water temperature $\left( \pm 0.1^{\circ}\right.$ C), salinity $( \pm 0.1)$ and $\mathrm{pH}( \pm 0.01)$ were measured during water sampling using a WTW Multiline P4 portable digital meter, previously calibrated. Dissolved oxygen was measured using a Hanna HI 9143 meter. At the laboratory, the water samples for nutrient analysis were filtered through glass fiber filters GF50/A 47mm, previously combusted at 450 ${ }^{\circ} \mathrm{C}$ and through 25-mm GF934/AH filters (Schleicher and Schuell) for analysis of chlorophylla. Aliquots of the filtrate were frozen for later analysis of chlorophyll-a, dissolved inorganic nitrogen (DIN: N-ammoniacal, nitrite, nitrate), orthophosphate and orthosilicate, dissolved organic nitrogen (DON) and dissolved organic phosphorus 

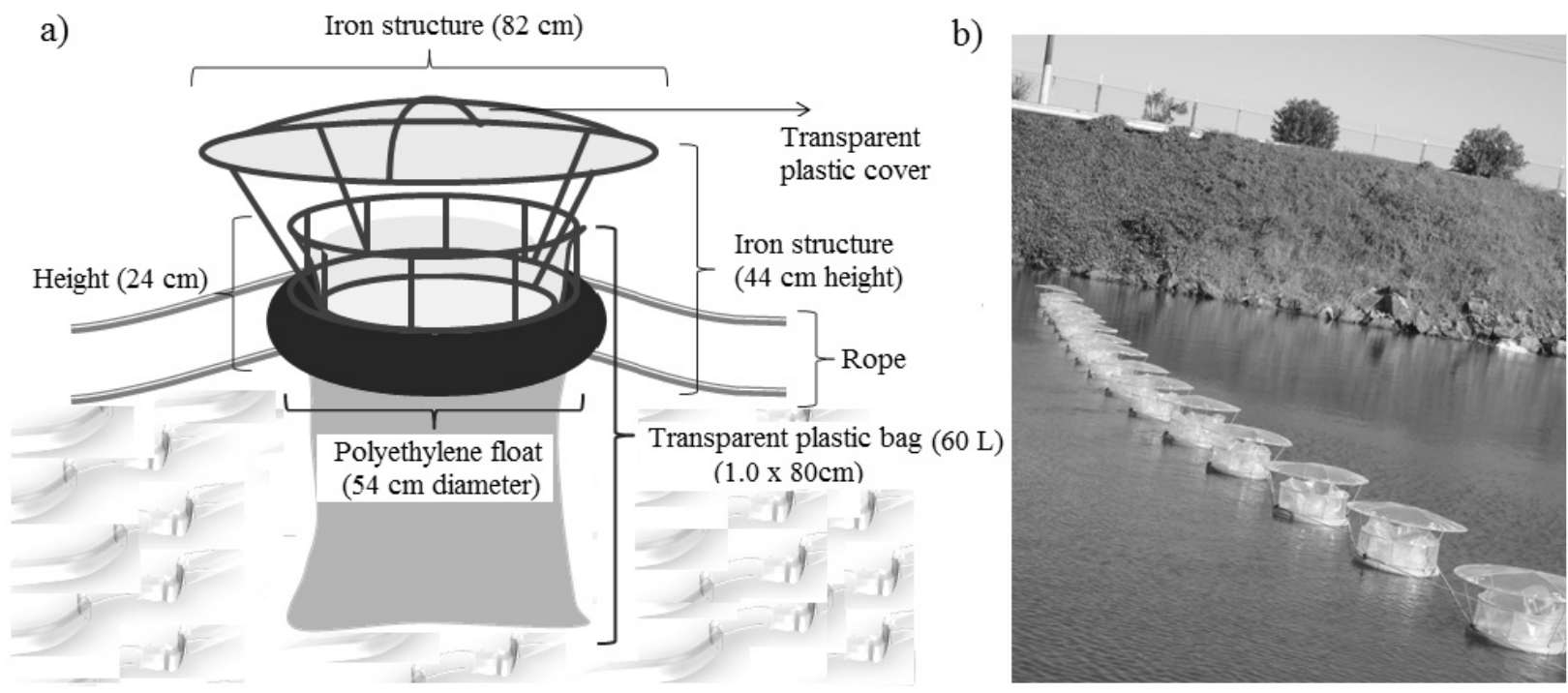

Figura 4. Schematic of the microcosm (a) image of the microcosm experiment assembled in the Ilhéus City Harbor (b).

(DOP).

Chlorophyll-a was extracted using 90\% acetone in the dark and cold $\left(-12^{\circ} \mathrm{C}\right)$ and analyzed according to the spectrophotometric method of Parsons et al. (1984), using a VIS Perkin Elmer spectrophotometer. The calculation of chlorophyll-a concentration was done according to Jeffrey and Humphrey (1975). Concentration of nutrients was determined by spectrophotometric methods according to Grasshoff et al. (1983) and dissolved silicate (orthosilicate) as described in Carmouze (1994). Nitrite was determined using the diazotation method (detection limit $0.02 \mu \mathrm{M}$ ); nitrate was determined by cadmium reduction into nitrite (nitrite limit plus a coefficient of variation $\pm 3 \%$ in the range 0-10 $\quad \mu \mathrm{M}$ ); ammonium was measured spectrophotometrically by the indophenol blue method (detection limit $0.05 \mu \mathrm{M}$ ); orthophosphate by the ascorbic acid molybdate method (detection limit $0.01 \mu \mathrm{M}$ ); dissolved silicate was determined by the ammonium molybdate method (detection limit $0.1 \mu \mathrm{M})$.

The dissolved organic nitrogen (DON) and phosphorus (DOP) were analyzed by digestion with persulfate (Grasshoff et al. 1983). After digestion, analysis followed the same methodology used for the inorganic nutrients. The organic fractions were obtained by the difference between inorganic nutrient concentrations (DIN and DOP) found in the samples digested with potassium persulfate. The detection limit is $0.2 \mu \mathrm{M}$ (DON) and $0.02 \mu \mathrm{M}$ (DOP).
Statistical Analysis: To perform the statistical test, the data were treated by division into three parts (beginning, middle, end) throughout the experiment: the beginning was the first five days of the experiment; the middle was the five intermediate days; and the end was the last five days. To compare the differences of nutrients and chlorophyll-a concentration between stations and periods, we used two-way analysis of variance (ANOVA), $\mathrm{p}(\alpha=0.05)$ with repeated measures. The comparison between means was performed using Fisher's as posteriori test $(p<0.05)$. When the data did not pass the test of normality and homoscedasticity, a logarithmic transformation was performed and the data were normalized using (Log10 (X +1) (Zar 1999).

\section{Results}

The ANOVA two-way test $p(\alpha=0.05)$ with repeated measures, evidenced that except for the water temperature, there is an interaction among the parameters of salinity, $\mathrm{pH}$, dissolved oxygen, total of suspend solids, as chlorophyll-a and nutrients $\left(\mathrm{NH}_{3}{ }^{+} \mathrm{NH}_{4}^{+}, \mathrm{NO}_{2}{ }^{-} \mathrm{NO}_{3}{ }^{-}, \mathrm{PO}_{4}{ }^{3-}, \mathrm{SiO}_{4}{ }^{-4}, \mathrm{DON}, \mathrm{DOP}\right.$; Table II).

Concerning the posteriori test comparation using Fisher's $(p<0.05)$, in both dry and rainy periods, the salinity ranged from 0.3 to 35.3 in the outer microcosms (3 and 4), which had salinity values significantly $(p<0.05)$ higher than the inner estuary portion (microcosms 1 and 2; Fig. 5a). Throughout the study, the temperature was significantly $(p<0.05)$ higher during the rainy period, which ranged from 26.6 to $29.1^{\circ} \mathrm{C}$ than in the dry 
Table II. Values obtained by Anova Two way (variance $\mathrm{F}$ and $\mathrm{p}$-value) for parameter interaction between periods (dry and rainy) and sampled stations

\begin{tabular}{ccc}
\hline Parameter & $\mathbf{F}$ & p-value \\
salinity & 8.4 & 0.0000 \\
Temperature & 2.1 & 0.0892 \\
$\mathrm{pH}$ & 13.8 & 0.0000 \\
Dissolved oxygen & 10.2 & 0.0000 \\
Total Suspend Solids & 5.8 & 0.0000 \\
$\mathrm{NH}_{3}{ }^{+} \mathrm{NH}_{4}{ }^{+}$ & 9.3 & 0.0000 \\
$\mathrm{NO}_{2}{ }^{-}$ & 4.1 & 0.0018 \\
$\mathrm{NO}_{3}{ }^{-}$ & 4.1 & 0.0005 \\
$\mathrm{PO}_{4}{ }^{-}$ & 8.4 & 0.0000 \\
$\mathrm{SiO}_{4}{ }^{-4}$ & 22.4 & 0.0000 \\
$\mathrm{DON}^{-}$ & 8.6 & 0.0000 \\
$\mathrm{DOP}^{-}$ & 4.2 & 0.0038 \\
chlorophyll-a & 67.5 & 0.0000 \\
\hline
\end{tabular}

period (Fig. 5b). At the beginning of the experiment, microcosms 1 and 2 had significantly $(p<0.05)$ higher mean temperature compared to 3 and 4 . In general the $\mathrm{pH}$, it varied from 6.36 to 9.03 in both periods, lower $\mathrm{pH}$ values were found at the beginning of incubation (Fig. 5c). During the dry period, the $\mathrm{pH}$ means in microcosms 1 and 2 were significantly $(p<0.05)$ higher than microcosms 3 and 4 and the opposite was observed in the rainy period. The dissolved oxygen saturation values ranged from $27.7 \%$ to $149 \%$ throughout dry and rainy periods (Fig. 5d). The dissolved oxygen saturation between the dry and rainy periods showed more variation in microcosms 1 and 2 especially during the beginning of the experiment than the microcosms 3 and 4 . These microcosms also tended to show more dissolved oxygen saturation than microcosms 1 and 2 (Fig. 5).

In general, in both periods the dissolved nitrogen concentrations in the inner estuary portion (microcosms 1 and 2) were significantly $(\mathrm{p}<0.05)$ higher than the outer estuary portion (3 and 4 microcosm) (Figs. 6a - 6d). In the microcosms 1 and 2 during the dry period, $\mathrm{N}$-ammoniacal, nitrite, and nitrate concentrations ranged from below the detection limit to a maximum $16.5 \mu \mathrm{M}, 2.81 \mu \mathrm{M}$ and $92.1 \mu \mathrm{M}$, respectively (Figs. 6a - 6c). In the rainy period, the concentrations ranged from below the detection limit to a maximum of $60.9 \mu \mathrm{M}$ $\left(\mathrm{NH}_{3}{ }^{+} \mathrm{NH}_{4}{ }^{+}\right), 2.60 \mu \mathrm{M}\left(\mathrm{NO}_{2}{ }^{-}\right)$and $84.4 \mu \mathrm{M}\left(\mathrm{NO}_{3}{ }^{-}\right)$
(Figs. 6a - 6c). For the microcosms 3 and 4 a range from below the detection limit to a maximum of $\mathrm{NH}_{3}{ }^{+} \mathrm{NH}_{4}{ }^{+}=4.8$ and $50.1 \mu \mathrm{M}$ was observed; $\mathrm{NO}_{2}{ }^{-}=$ 1.1 and $1.5 \mu \mathrm{M} ; \mathrm{NO}_{3}{ }^{-}=7.1$ and $25.1^{\mu} \mathrm{M}$ (to the dry and rainy periods, respectively). With the exception to the microcosm 4, the maximum of DIN concentration was observed in the beginning of the experiment (until day 5) (Fig. 6).

Concerning the dissolved inorganic nitrogen (DIN) variation through the microcosm experiment, the maximum value was observed until day 5 . Afterwards, the concentrations decreased in all microcosms (Figs. 6a - 6b). At the end of the experiement in the rainy period, there was an increase of the $\mathrm{N}$-ammoniacal and nitrite concentrations (Figs. 6a - 6b). It was also observed that the nitrate concentrations were higher than $\mathrm{N}$ ammoniacal at the beginning of the experiments (Fig. 6c). In microcosms 1 and 2, during the dry period, a peak of nitrate was observed in day 2, coinciding with a decrease in $\mathrm{N}$-ammoniacal concentration, and it was significantly $(p<0.05)$ higher compared to microcosms 3 and 4 (Fig 6c). In microcosm 1 during the dry period, at the beginning of the experiment, the nitrate means were significantly $(p<0.05)$ higher compared to the rainy period (Fig 6c).

In the inner estuary portion the dissolved organic nitrogen (DON) concentrations started to increase on day 3 and were significantly $(p<0.05)$ higher than the outer estuary portion that started to increase on day 5 (Fig. 6d). The DON concentration increased as the experiment progressed. In microcosm 1 and 2 the values ranged from the detection limit to 104.1 凡 $\mathrm{M}$ (rainy period) and varied to a maximum of $80.1 \mu \mathrm{M}$ (dry period). However, for the microcosms 3 and 4 the DON concentration in the rainy and dry periods did not exceed $70.1 \mu \mathrm{M}$ (Fig.6d). However, in microcosm 2 at the beginning of the experiment, the DON was a significantly $(p<0.05)$ higher in the dry period compared to the rainy period.

The phosphate concentrations were significantly $(p<0.05)$ higher in the inner than the outer estuary portion in both dry and rainy periods (Fig. 7a). In microcosms 1 and 2 a range below the detection limit to a maximum of $15.9 \mu \mathrm{M}$ was observed in the dry period, and up to $12.9 \mu \mathrm{M}$ in the rainy period (Fig. 7a). In microcosms 3 and 4, respectively, a range below the detection limit to a maximum of 3.1 and $0.91 \mu \mathrm{M}$ was observed in the dry period and, to 5.8 and $0.51 \mu \mathrm{M}$ in the rainy period. In the microcosms 1 and 2, in the beginning 


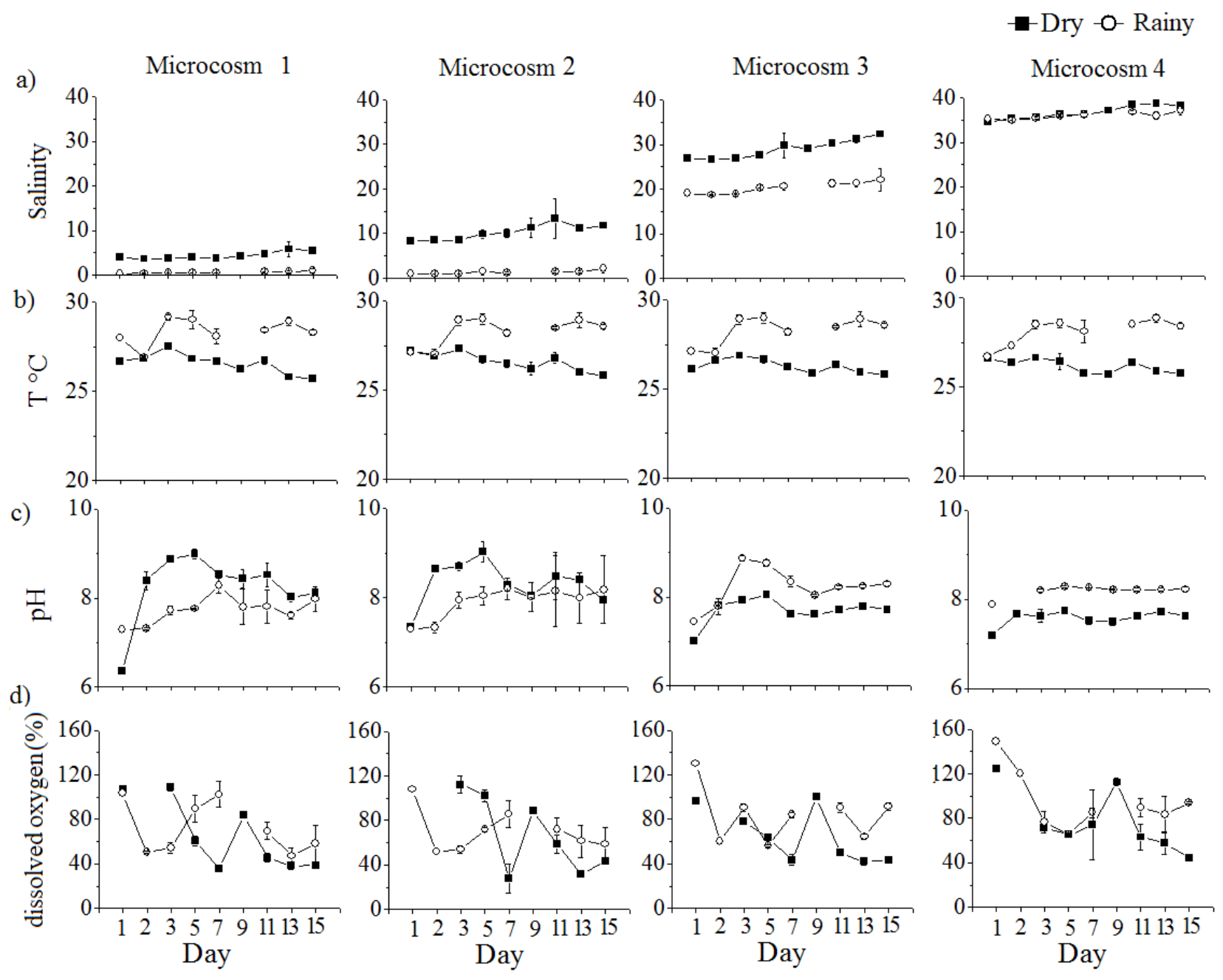

Figure 5. Salinity variation (a), Temperature $-\mathrm{T}^{\circ}$ (b), $\mathrm{pH}$ (c) Saturation of dissolved oxygen (d) in a microcosm experiment during 15 days. The bars indicate the standard deviation. Dry Period = closed square and Rainy Period $=$ open cycle. The microcosms (1-4) are referring their 4 sampling stations. Note the difference in scale

of the experiment, the phosphate concentrations were higher during the rainy period compared to the dry period. With the exception of microcosm 4 , it was observed that the $\mathrm{PO}_{4}{ }^{3-}$ concentration decreased until day 5 , and only in microcosm 2 during the dry period, a significant $(p<0.05)$ phosphate increase was registered in the end of the experiment (Fig. 7a).

For the dissolved organic phosphorus (DOP), significantly $(p<0.05)$ higher concentrations were observed in the inner portion than the outer estuary portion for dry and rainy periods (Fig. 7b). The DOP varied throughout the incubation in distinct patterns along to the estuary portions. Only in the inner portion, a significantly $(\mathrm{p}<0.05)$ higher concentration was detected during the rainy compared to the dry period. Thus, in microcosms 1 and 2 a range from below the detection limit to a maximum of $5.20 \mu \mathrm{M}$ (in the dry period) was observed and to $9.94 \mu \mathrm{M}$ in the rainy period
(Fig.7b). Regarding the outer portion, during the dry period, a DOP concentration below the detected limit was observed until day 11, when DOP began to increase at the end of experiment, to significantly $(p<0.05)$ higher concentrations as compared to the rainy period. Only in microcosm 3 , during the rainy period, was a maximum of $1.2 \mu \mathrm{M}$ was observed in the beginning of the incubation on day 2 (Fig.7b).

For both periods (dry and rainy) the silicate concentrations were more elevated in the inner estuary portion (dry= from 10.1 to $60.1 \mu \mathrm{M}$ and rainy= ranged from 90.1 to $275.1 \mu \mathrm{M}$ ) than in the outer portion (dry= variated from 5.21 to $30.1 \mu \mathrm{M}$ and rainy= from 2.10 to $51.2 \mu \mathrm{M}$; Fig. 7c).

It is important to note that during the dry period, between days 3 and 7, silicate was not analyzed. Regarding the $\mathrm{SiO}_{4}^{-4}$ fluctuation throughout the experiment, except in microcosm 4, it was identified that, in the rainy period the concentrations increased 

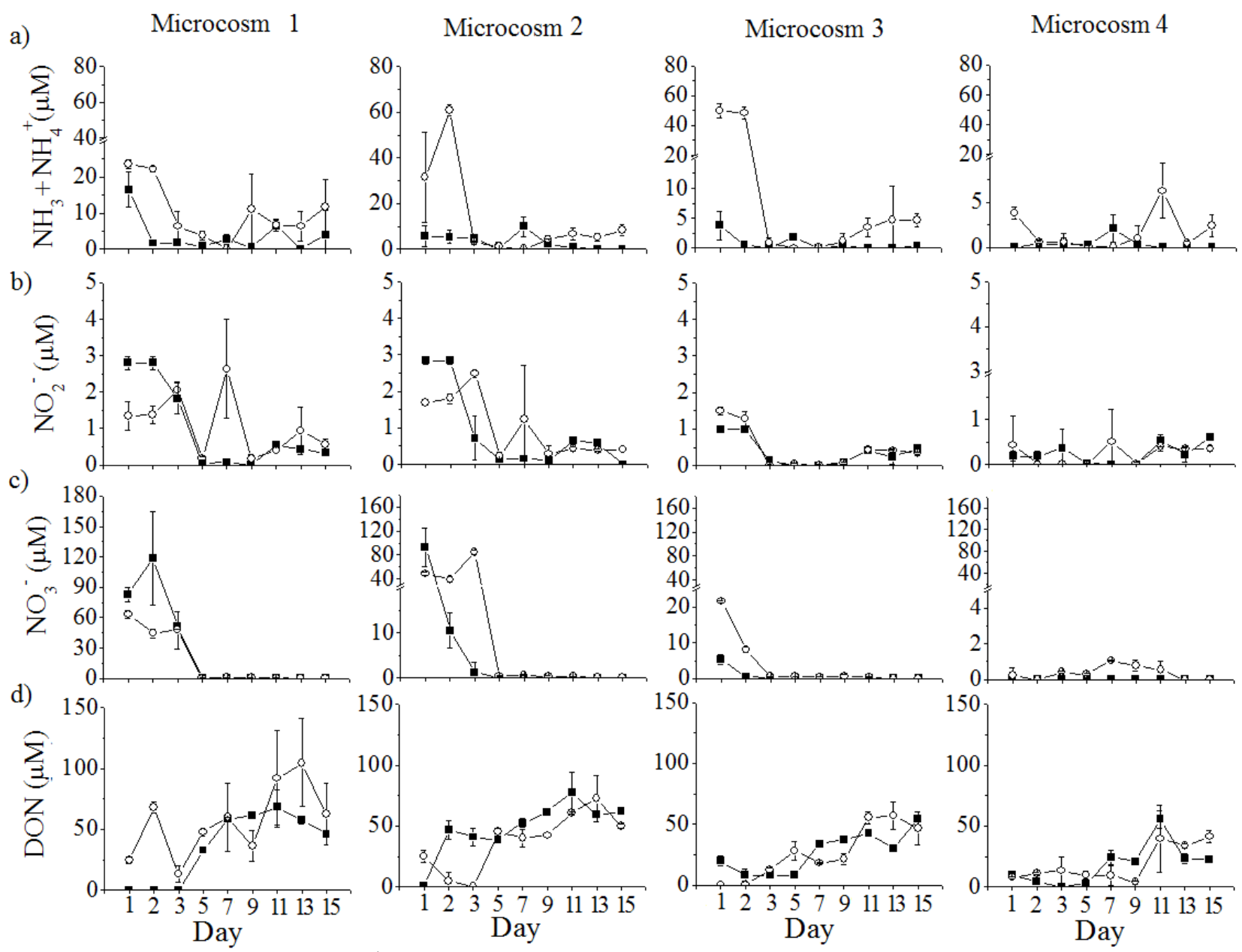

Figure 6. Concentrations variation ( $(\widehat{\Re} \mathrm{M})$ of $\mathrm{N}$-ammoniacal $-\mathrm{NH}_{3}^{+} \mathrm{NH}_{4}^{+}$(a), nitrite $-\mathrm{NO}_{2}^{-}$(b) nitrate $-\mathrm{NO}_{3}^{-}$, (c) and Dissolved Organic Nitrogen - DON (d) in a microcosm experiment with a duration of 15 days. The error bars indicate the standard deviation. Dry Period = closed square and Rainy Period = open circle. The microcosms (1-4) are referring their 4 sampling stations. Note the difference in scales.

in the beginning of incubation with a maximum value on day 3 (especially for microcosms 1 and 2) and started to decrease until they were constant in the end of incubation (day 9; Fig. 7c).

The Chlorophyll-a concentrations registered in the inner estuary portion were more elevated than the outer portion (Fig. 7d). Thus, in the inner portion, chlorophyll-a concentrations at the beginning of the experiment were significantly $(\mathrm{p}<0.05)$ higher in the dry period (maximum value of $249.1 \mu \mathrm{g} / \mathrm{L}$ and $728 \mu \mathrm{g} / \mathrm{L}$ for microcosms 1 and 2, respectively) than in the rainy period (maximum value of $111.1 \mu \mathrm{g} / \mathrm{L}$ for both microcosms 1 and 2). In the middle of the experiment, the chlorophyll-a mean in microcosms 1 and 2 was significantly $(p<0.05)$ higher during the rainy compared to the dry period, and reached a peak of about $100.1 \mu \mathrm{g} / \mathrm{L}$ on day 5 of incubation (Fig. 7d). In the dry period, except in microcosm 2, an increase of Chlorophyll-a concentrations was observed in day 2 of incubation reaching a maximum and after that, the concentrations started to decrease (Fig. 7d). In microcosm 2, in the middle of the experiment (between days 7 and 9) after the lowest value, the chlorophyll-a concentrations started to increase again (Fig. 7d).

\section{Discussion}

Nutrient concentration difference between the rainy and the dry periods and inner and outer portions reflects the river discharge role on phytoplanktonic biomass, DON, DIN, DOP, phosphate and silicate dynamics in the Cachoeira River estuary. It is suggested that the increase in nutrients observed from inner to outer estuary portions are derived mainly from anthropogenic 

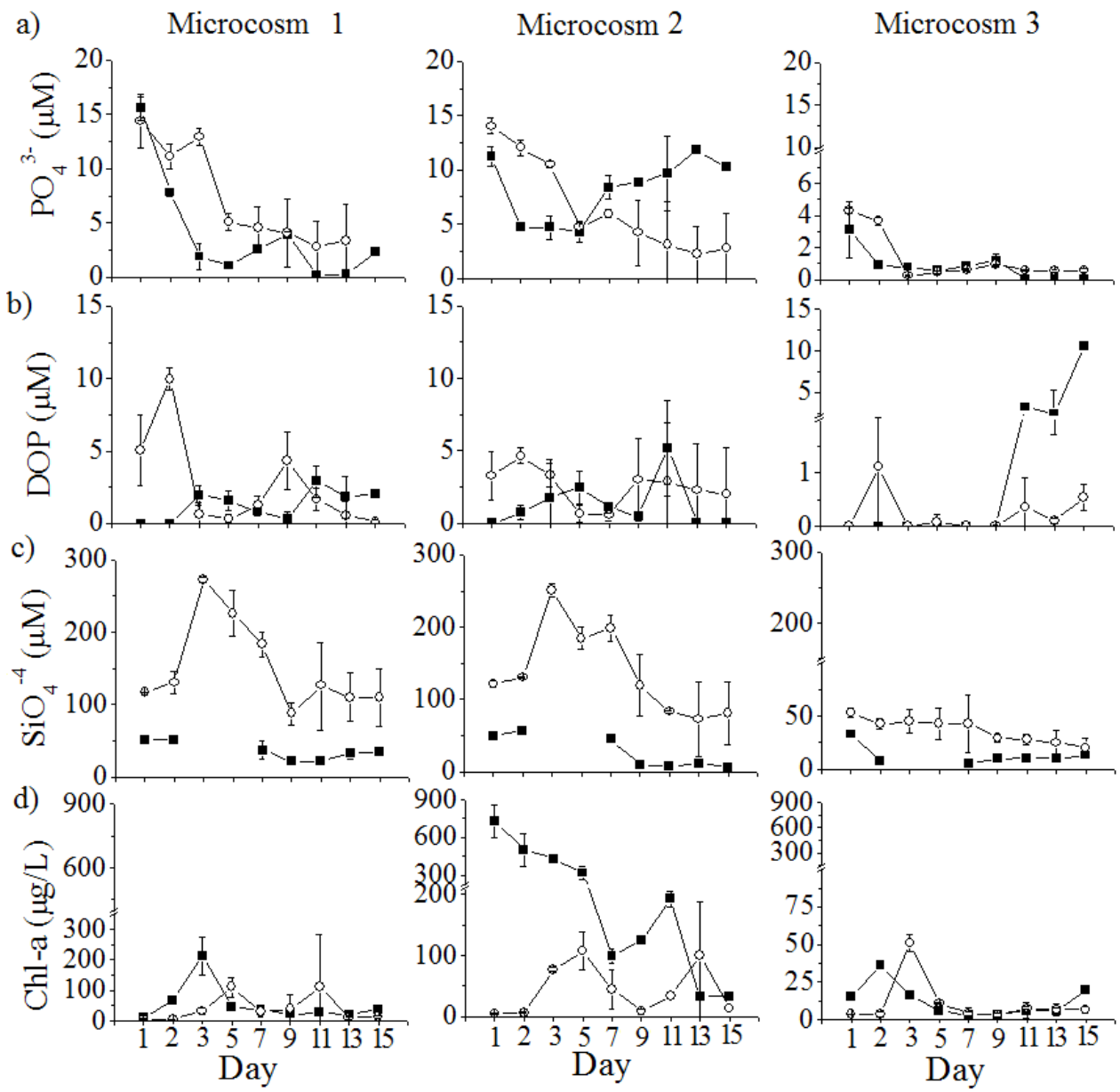

Dry -O-Rainy

Microcosm 4
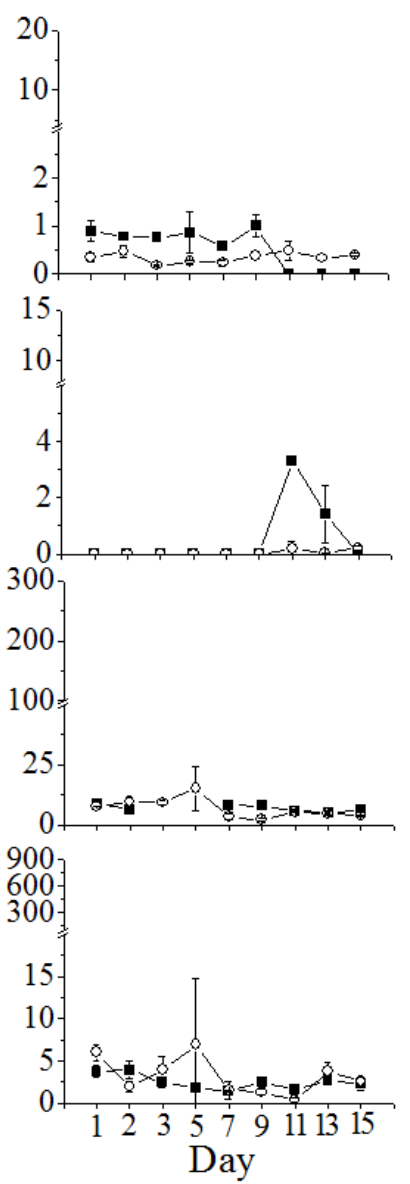

Figura 7. Concentrations variation $(\mu \mathrm{M})$ of Phosphate $-\mathrm{PO}_{4}^{-3}$ (a), Dissolved Organic Phosphorus - DOP (b), Silicate $\mathrm{SiO}_{4}^{-4}$ (c) and Chlorophyll-a (d) in a microcosm experiment during 15 days. The bars indicate the standard deviation. Dry Period = closed square and Rainy Period = open cycle. The microcosms (1-4) are referring their 4 sampling stations. Note the difference in scale.

sources. For example, the sewage effluent of the treatment plant is located at the inner portion of this estuary and raw sewage is released directly into the Cachoeira River. The anthropogenic source of the sewage effluent from the treatment plant to the inner portion affecting the dissolved inorganic nutrients concentrations in situ of the Cachoeira River estuary was also described by Klumpp et al. (2002), Souza (2005), Souza et al. (2009), Lima et al. (2010), Lucio et al. (2012), Silva et al. (2013, 2015), Santos et al. (2018), and Cerqueira et al. (2020). In this case, the nutrient decrease observed in the outer portion confirms the potential for a greater water renewal and dilution in the outer estuary suggested by Souza (2005), Souza et al. (2009), Silva et al. (2013).

In inner portion (microcosms 1 and 2) especially in the beginning of the incubation (until day 5), during the rainy period, the DON, DOP, N- ammoniacal, phosphate and silicate concentrations were higher than the dry period, due to increased input of these nutrients from the watershed into the estuary. Additionally, increasing river discharges lead to a greater transport of nutrients derived from sewage effluents that are dumped into the Cachoeira River estuary. Conversely, the chlorophyll-a concentration, which in this study was measured as a proxy for the phytoplankton biomass, was higher in the dry compared to the rainy period. This is possible because of the longer residence time of water in the estuary during the dry period the water transparency is commonly greater than in the rainy period. Silva (2012) confirmed that observed that during the dry period (August of 2009) the estimate to the water residence time was 7 days and to the rainy period (April of 2010) was 3 days. In the inner portion, in both dry and rainy periods it is believed that the main biological process that occurred, at the 
beginning of the experiment, was the assimilation of the nutrients by phytoplankton. This may be indicated by the trend of $\mathrm{N}$-ammoniacal, nitrite, nitrate, and phosphate to decrease as the increase of DON, DOP, and Chlorophyll-a concentrations.

Similarly, the increase of the silicate in the microcosms during the rainy period was clearly observed in the inner portion, is also likely to be the result of biogenic silicate regeneration, produced through the action of bacteria. The increased concentration of silicate throughout the microcosm experiment was also observed by Jesus \& Odebrecht (1999) using water from the Patos Lagoon estuary in Rio Grande do Sul State. These authors suggested that the increase of silicate may be caused by the dissolution of silica. The regeneration of silicate by bacteria occurs through the activity of hydrolytic enzymes, which act on the cell walls of diatoms, removing the protective layer of organic diatomaceous and exposing walls of silica that increases its dissolution (Smetacek 1999, Bidle \& Azam 2001, Schultes et al. 2010). The activity of microzooplankton grazing on diatoms can also accelerate the silica dissolution process.

An exception was observed in microcosm 2 during the dry period that registered a maximum value of chlorophyll-a concentration between days 1 and 5, and after that, chlorophyll-a decreased seven times until day 7. Another Chlorophyll-a peaked in the middle of the experiment (days 7-11), which can be attributed to a bloom that occurred in the estuarine site (STP station - 2) and after that, even absorbing nutrients during the incubation, phytoplankton cells probably died due to light limitation. The senescence of phytoplankton in microcosm 2 is confirmed by the trend to increase of DON parallel to the chlorophyll-a decrease. Similar results were registered by Edwards et al. (2005), using water from a shallow lagoon (Rio Formosa) and ocean water (Sagres) in microcosm experiments, where after the lowest value, the chlorophyll-a restarted to increase with the increase of dissolved organic nutrients.

Based on the chlorophyll-a concentrations in the microcosms it was suggested that in the water of the Cachoeira River estuary, phytoplankton assimilation was the main removal mechanism of $\mathrm{N}$ ammoniacal and that nitrate was used by the primary producers in the experiment. Considering that in both dry and rainy periods, the $\mathrm{NH}_{3}{ }^{+}$and $\mathrm{NH}_{4}{ }^{+}$ concentrations did not decrease when nitrate concentration increased, we instead suggest that the microcosms demonstrate that nitrification is not the only responsible process for the removal of $\mathrm{N}$ ammoniacal. Mixing diagram data from surveys throughout this estuary indicate the prevalence of nitrification and denitrification alternately in different months (Souza et al. 2009, Silva et al. 2013, 2015). The influence of denitrification in the water column on nitrogen concentrations is the result of benthic-pelagic interaction present in natural environments. Thus, in addition to nitrogen assimilation by phytoplankton, the coupling between nitrification and denitrification is also important in the removal of DIN in the estuary.

Only in the inner portion we clearly observed that between both dry and rainy periods, at the beginning of the incubation, the nitrate was higher than the $\mathrm{N}$-ammoniacal concentrations. This may indicate that the nitrification process had occurred in the estuarine water column and /or sewage treatment plant, and that the nitrate was also transported by the soil from the drainage basin of the estuary. The dissolved inorganic nitrogen ( $\mathrm{N}$-ammoniacal, nitrite, and nitrate) and phosphate were removed at the beginning of the experiment (between days 1 and 5), reaching low values after these days.

Regardless of the time of year and period of collection in the estuary, the DON concentrations throughout the experiments showed a similar pattern. In all microcosms, the higher DON values were observed from the middle to the end of incubation. The increasing trend of DON concentrations throughout the incubation, especially in the inner portion, offer evidence to consider both processes as organic matter decomposition and nutrient regeneration. The DOP concentration did not show a regular pattern but also increased throughout the incubation period. DOP and DON concentrations are released by the bacteria into the environment through the decomposition of organic matter. They are also liberated by herbivorous sloppy feeding, excretion or incomplete digestion (Pérez-Aragon et al. 1984, Hasegawa et al. 2000, Berman \& Bronk 2003) and exudation of phytoplankton cells, death and cell lysis (Nausch \& Nausch 2006) claim that the release of DOP by cyanobacteria occurs mainly during cell death. Besides these factors, physiological stressors such as nutrient limitation and temperature can also increase the production of DOP and DON (Myklestad 1995, Zehr \& Ward 2002).

Interestingly, in both the dry and rainy periods the DON concentrations were higher than other nitrogenous forms in the microcosms. In fact, in many natural waters, DON concentrations are higher 
than DIN, fraction comprising ammonium $\left(\mathrm{NH}_{4}{ }^{+}\right)$, nitrate $\left(\mathrm{NO}_{3}{ }^{-}\right)$and nitrite $\left(\mathrm{NO}_{2}{ }^{-}\right)$. The autochthonous sources may include release by exudation from phytoplankton, and bacteria, from cell death or viral lysis, or from zooplankton grazing and excretion (Berman \& Bronk 2003). However, concentrations of DON and DOP were higher in microcosms 1 and 2 , which were from water collected from the inner portion of the estuary. In that portion, a higher concentration of phytoplanktonic biomass was observed, but also a greater input of organic matter from river sources and from the sewage treatment plant. In these microcosms, high phytoplankton production, expressed as an increase of chlorophyll$a$ in the middle and end of the experiment, may be largely sustained by DON uptake.

Traditionally, DON used to be seen as a large "pool" of refractory $\mathrm{N}$, which only contributed to bacterial production (Bronk et al. 2007). This is because aquatic bacteria are capable of using a variety of DON that can be sources of nitrogen and carbon for biosynthesis or may be used as sources of energy (Kroer et al. 1994). The ability of these microorganisms to use the DON is due to excretion of proteolytic enzymes that digest peptides and proteins, such that the monomers or oligonucleotides can be absorbed and metabolized by bacteria. However, other studies have shown the importance of DON as a nutrient source for primary production, including some noxious species of phytoplankton, which can obtain a substantial part of its nutrition from organic compounds (Berman \& Bronk 2003, Bronk et al. 2007, Cochlan et al. 2008, Bradley et al. 2010). Like DON, several studies have reported the use of DOP by phytoplankton, especially in the case of phosphorus deficiency, and also by bacterioplankton (Lomas et al. 2010, Yoshimura \& Kudo 2011, Wang et al. 2011).

\section{Conclusion}

The microcosm experiments revealed that there is no clear pattern of phytoplanktonic biomass (chlorophyll-a), DON, DIN, DOP, phosphate, and silicate concentrations between the rainy and the dry periods in the Cachoeira River estuary portions. However, in the inner portion the majority of the nutrient concentrations were higher in the rainy period than in the dry period, due to increased input of these nutrients from the watershed into the estuary. The highest nutrient concentration and the majority of the biological process were observed mainly in the inner estuary portion, reflecting the STP and the river discharge influence on the
Cachoeira River estuary. The depletion of inorganic nitrogen and phosphate associated with an increase in DON and chlorophyll-concentrations are mainly related to the assimilation by phytoplankton. Although $\mathrm{N}$-ammoniacal is the preferred form of nitrogen for phytoplankton, nitrate represented a major source of nitrogen for primary producers in this experiment, and it was totally depleted from the system. Nitrification seems to occur, but it is possibly not the most important mechanism in the removal of $\mathrm{N}$-ammoniacal in microcosm. DON and DOP were probably also used by phytoplankton and may play a relevant role in the dynamics of nutrients in the water column of the estuary of the Cachoeira River.

\section{Acknowledgments}

We thank Mr. Ruy Cavalcanti and colleagues from the laboratory for help with fieldwork and Fernanda Silva for his help in chemical analysis. MAM Silva would like to thank the Coordenação de Aperfeiçoamento de Pessoal de Nível Superior (CAPES) - CAPES Edital Pró-Amazônia Azul 04/2006 for granting the support of her doctorate (Proc. No. 004 ED04/2006). The Universidade Estadual de Santa Cruz for support in developing the work and the Programa de Pós-Graduação em Oceanografia Biológica of Universidade Federal do Rio Grande. Silva would also like to acknowledge also the Companhia das Docas do Estado da BahiaCODEBA especially Mr. Eduardo Melquiades for facilitating the development of the experiments within the harbor of Ilhéus, and Erika Koontz for the English review.

\section{References}

Bahia, 2001. Programa de Recuperação das Bacias dos Rios Cachoeira e Almada. Diagnóstico

Regional. Caracterização Hidrológica. Ilhéus, SRH/UESC, accessible at http://www.meioambiente.ba.gov.br. (Accessed 05/01/2011).

Berman, T., \& Bronk, D. A. 2003. Dissolved organic nitrogen: a dynamic participant in aquatic ecosystems. Aquatic microbial ecology, 31(3), 279-305.

Bidle, K. D., \& Azam, F. 2001. Bacterial control of silicon regeneration from diatom detritus: Significance of bacterial ectohydrolases and species identity. Limnology and Oceanography, 46 (7): 1606 -1623. 
Bradley, P. B., Sanderson, M. P., Frischer, M. E., Brofft, J., Booth, M. G., Kerkhof, L. J. \& Bronk, D.A.

2010. Inorganic and organic nitrogen uptake by phytoplankton and heterotrophic bacteria in the stratified Mid-Atlantic Bight. Estuarine, Coastal and Shelf Science, 88 (4): 429-441.

Bronk, D.A., See J. H., Bradley, P. \& Killberg L. 2007. DON as a source of bioavailable nitrogen for phytoplankton. Biogeosciences, 4 (3): 283-296.

Carmouze, J. P. 1994. O metabolismo dos ecossistemas aquáticos. Edgar Blucher, São Paulo, 253p.

Carvalho, T.M., \& Fidélis, T. 2013. The relevance of governance models for estuary management plans. Land Use Policy, 34:134-145.

Cerqueira, T.C., Mendonça. R.L., Gomes, R.L., Jesus, R.M. \& Silva, M. L. 2020. Effects of urbanization on water quality in a watershed in northeastern Brazil. Environmental Monitoring and Assessment, 192 (65): https://doi.org/10.1007/s10661-019-8020-0

Cochlan, W. P., Herndon, J.\& Kudela, R. M. 2008. Inorganic and organic nitrogen uptake by the toxigenic diatom Pseudo-nitzschia australis (Bacillariophyceae). Harmful Algae, 8 (1): 111-118.

Davies, P. L. \& Eyre, B. D. 2005. Estuarine modification of nutrient and sediment exports to the Great

Barrier Reef Marine Park from the Daintree and Annan River Catchments. Marine Pollution Bulletin, 51 (1-4): 174-185.

Dugdale, R. C., Wilkerson, F. P., Hogue, V. E. \& Marchi, A. 2007. The role of ammonium and nitrate in spring bloom development in San Francisco Bay. Estuarine, Coastal and Shelf Science, 73(1-2): 17-29.

Edwards, V., Icely, J., Newton, A. \& Webster, R. 2005. The yield of chlorophyll from nitrogen: a comparison between the shallow Ria Formosa lagoon and the deep oceanic conditions at Sagres along the southern coast of Portugal. Estuarine, Coastal and Shelf Science, 62 (3): 391-403.

Fukushima, T., Ishibashi, T. \& Imai, A. 2001. Chemical characterization of dissolved organic matter in Hiroshima Bay, Japan. Estuarine, Coastal and Shelf Science, 53(1): 51-62.

Grasshoff, K., Ehrardt, M. \& Kremling, K. (Eds.). 1983. Methods of Seawater Analysis. Verlag
Chemie Weinheim/Deerfield Beach, Florida, $419 \mathrm{p}$.

Guimarães, A. G. 2006. Tempo de residência da água e estado trófico da porção interna do estuário do rio Cachoeira, Ilhéus-BA. Masters Thesis. Universidade Estadual de Santa Cruz, Ilhéus, Brazil, 118p.

Hasegawa, T., Koike, I., Muka, H. (2000). Estimation of dissolved organic nitrogen release by micrograzers in natural planktonic assemblages. Plankton Biology and Ecology, 47 (1), 23-30.

Halpern, B.S., Walbridge S., Selkoe, K.A., Kappel, C.V., Micheli, F., D’Agrosa, C., Bruno, J.F., Casey, K.S., Ebert, C., Fox, H.E., Fujita, R., Heinemann, D., Leniah, H.S., Madin, E.M.P., Perry, M.T., Selig, E.R., Spalding, M., Steneck, R., \& Watson, R. 2008. A Global Map of Human Impact on Marine Ecosystems. Science, 319 (5865): 948-952.

IBGE, 2020. Instituto Brasileiro De Geografia e Estatística. Accessible at http://www.ibge.gov.br/cidades-e-estados/ba/it abuna.html (accessed 02/02/2020).

Jeffrey, S.W., \& Humphrey, G.F. 1975. New spectrophotometric equations for determining chlorophylls a, b, c and c2 in higher plants, algae and natural phytoplankton. Biochemie und Physiologie der Pflanzen, 167(2): 191194.

Jesus, A. R. S., \& Odebrecht, C. 1999. Fitoplâncton e nutrientes inorgânicos no Estuário da Lagoa dos Patos: Experimentos de enriquecimento em laboratório. Atlântica, 21: 59-75.

Klumpp, A., Bauer, B.K., Gerstein, C.F. \& Menezes, M. 2002. Variation of nutrient and metal concentration in aquatic macrophytes along the Rio Cachoeira in Bahia (Brazil). Environment International, 28(3): 165-171.

Kroer, N., Coffin, R.B. \& Jørgensen, N.O.G. 1994. Comparison of microbial trophic interactions in aquatic microcosms designed for the testing of introduced microorganisms. Environmental Toxicology and Chemistry, 13 (2): 247-257.

Lomas, M. W., Burke, A. L., Lomas D. A., Bell, D.W., Shen, C., Dyhrman S.T., \& Ammerman, J.W. (2010).

Sargasso Sea phosphorus biogeochemistry: an important role for dissolved organic phosphorus (DOP). Biogeosciences, 7 (2): 695-710. 
Lima, M.C., Souza, M. F. L., Eça, G. F. \& Silva, M. A. M. 2010. Export and retention of dissolved inorganic nutrients in the Cachoeira River, Ilhéus, Bahia, Brasil. Journal Limnology, 69(01): 138-145.

Lucio, M.Z.T.P.Q.L., Santos, S.S. \& Silva, D.M.L. 2012. Hydrochemistry of Cachoeira River (Bahia State, Brazil). Acta Limnologica, Brasiliensia, 24(2):181-192.

Marques, M., Knoppers, B. A., Lana, A., Abdallah, A., \& Pollette, M. 2004 (Eds.). Brazil Current, GIWA Regional Assessment 39. Accessible

at

http://www.unep.org/dewa/giwa/areas/reports/ r39/giwa regional assessment 39.pdf.

(Accessed 07/14/2014).

Mckee, L. J., Eyre B. D. \& Hossain S. 2000. Transport and retention of nitrogen and phosphorus in the subtropical Richmond River estuary, Australia - A budget approach. Biogeochemistry, 50 (3): 241-278.

McLusky, D.S., \& Elliott, M. 2004. The Estuarine Ecosystem. Ecology, threats and management. University Press, Oxford, 222 p.

Myklestad, S.M. 1995. Release of extracellular products by phytoplankton with special emphasis on polysaccharides. Science of The Total Environment, 165(1-3): 155-164.

Melo, C.R., Melo, S.C., Silva, J.F.R., Guedes, P.A., Luna, D.S. (2014). Análise quali-quantitativa da Bacia do Rio Cachoeira (BA). XII Simpósio de Recursos Hídricos do Nordeste, accessible at http://www.abrh.org.br/xiisrhn/anais/papers/P AP018343.pdf. (Accessed 12/20/2019).

Nausch, M., \& Nausch, G. 2006. Bioavailability of dissolved organic phosphorus in the Baltic Sea. Marine Ecology Progress Series, 321, 9-17.

Nixon, S. W. 1995. Costal Marine Eutrophication: A definition, social causes, and future concern. Ophelia, 41, 199-219.

Parsons, T.R., Maita, Y. \& Lalli, C.M. 1984. A manual of chemical and biological methods for seawater analisys. Pergamon Press, Oxford, $184 \mathrm{p}$.

Pérez-Aragon, M., Fernandez, C.\& Escribano, R. 2011. Nitrogen excretion by mesozooplankton in a coastal upwelling area: Seasonal trends and implications for biological production. Journal of Experimental Marine Biology and Ecology, 406 (1-2): 116-124.
Pinckney, J.L., Paerl, H. W., Tester, P. \& Richardson, T. L. 2001. The Role of Nutrient Loading and Eutrophication in Estuarine Ecology. Environmental Health Perspectives, 109 (5): 699-706.

Rabalais, N. N. 2002. Nitrogen in Aquatic Ecosystems. Ambio, 31(2): 102-112.

Santos, B., Silva, M.A.M., Souza, M.F.L. \& Silva, D.M.L. 2018. Nitrogen distribution in a tropical urbanized estuarine system in northeastern Brazil. Environmental Monitoring and Assessment, https://doi.org/ 10.1007/s10661-017-6420-6

Schultes, S., Lambert, C., Pondaven, P., Corvaisier, R.\& Jansen, S. 2010. Recycling and Uptake of $\mathrm{Si}(\mathrm{OH}) 4$ when Protozoan Grazers Feed on Diatoms. Protist, 161(2): 288-303.

Silva, M. A. M., Eça, G. F., Santos, D. F., Guimarães, A. G., Lima, M. C. \& Souza, M. F. L. 2013. Dissolved inorganic nutrients and chlorophyll-a in an estuary receiving sewage treatment plant effluents: Cachoeira River estuary (NE Brazil). Environmental Monitoring and Assessment, 185(7): 53875399.

Silva, M. A. M., Souza, M. F. L.\& Abreu, P. C. 2015. Spatial and temporal variations of dissolved inorganic nutrients, and chlorophyll-a in a tropical estuary in northeastern Brazil: dynamics of nutrient removal. Brazilian Journal of Oceanography, 63(1): 1-15.

Silva, A.S.M. 2012. Variabilidade dos nutrientes e da biomassa fitoplanctônica no estuário do rio Cachoeira, lhéus, BA - Brasil. PhD. Thesis. Universidade Federal do Rio Grande, RS, Brazil, 110p.

Smetacek, V. 1999. Diatoms and the ocean carbon cycle. Protist, 150 (1): 25-32.

Smith, V.H., Tilman, G.D. \& Nekola, J.C. 1999. Eutrophication: impacts of excess nutrient inputs on freshwater, marine, and terrestrial ecosystems. Environmental Pollution, 100 (1-3): 179-196.

Souza, M. F. L. 2005. Nutrient biogeochemistry and mass balance of a tropical estuary: estuary of Cachoeira River, Northern Brazil. Internatioal Journal of Ecology and Environmental Sciences, 31(3): 177-188.

Souza, M. F. L., Eça, G. F., Silva, M. A.M., Amorim, F. A. C.\& Lôbo, I. P. 2009. Distribuição de nutrientes dissolvidos e clorofila-a no Estuário do Rio Cachoeira, Nordeste do Brasil. Atlântica, Rio Grande, 31(1): 107-121. 
Syvitski, J.P.M., Vörösmarty,C., Kettner, A.J. \& Green, P. (2005). Impact of Humans on the Flux of Terrestrial Sediment to the Global Coastal Ocean. Science, 308 (5720): 376-380.

Turner, R.E., Rabalais, N.N., Justic, D., Dortch, Q. (2003). Future Aquatic Nutrient Limitations. Marine Pollution Bulletin, 46 (8): 10321034.

Vitousek, P.M., Aber, J.D., Howarth, R.W., Likens, G.E., Matson, P.A., Schindler, D. W., Schlesinger, W.H. \& Tilman. G.D (1997). Human alteration of the global nitrogen cycle: sources and consequences. Science, 7(3): 737-750.

Wang, Z., Liang Y.\& Kang, W. 2011. Utilization of dissolved organic phosphorus by different groups of phytoplankton taxa. Harmful Algae, 12, 113-118.
Yoshimura, T., \& Kudo, I. 2011. Seasonal phosphorus depletion and microbial responses to the change in phosphorus availability in a subarctic coastal environment. Marine Chemistry, 126 (1-4): 182-192.

Zapata, C., Puente, A., García, A., García-Alba, J. \& Espinoza, J. 2018. Assessment of ecosystem services of an urbanized tropical estuary with a focus on habitats and scenarios. Plos One, https://doi.org/10.1371/journal.pone.0203927

Zar, J.H. (1999). Biostatistical analysis. PrenticeHall Inc, New Jersey, 663 p.

Zehr, J.P., \& Ward, B. B. 2002. Nitrogen Cycling in the Ocean: New Perspectives on Processes and Paradigms. Applied Environmental Microbiology, 68 (3): 1015-1024.

Received: February 2021

Accepted: October 2021

Published: November 2021 


\section{PANAMJAS}

\section{Nutrient dynamics in a tropical estuary: a microcosm approach}

Maria Aparecida Macedo da Silva ${ }^{1 *}$, Eline Nayara Dantas da Costa ${ }^{1}$, Marcelo Friederichs Landim Souza ${ }^{1}$ \& Paulo CESAR OLIVEIRA VERGNE ABREU²

${ }^{1}$ Universidade Estadual de Santa Cruz - UESC, Laboratório de Biogeoquímica Marinha, Rod. Ilhéus-Itabuna km 16, 45650-000, Ilhéus, BA, Brasil

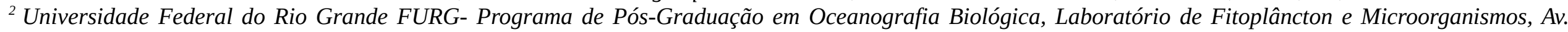
Itália, Km 08, 96201-900, Rio Grande, RS, Brasil.

*Corresponding author: cidahmacedo@yahoo.com

\section{Supplementary Material}

Table SI 
Table SI Monthly precipitation average (mm) and standard deviation from 1999 to 2010 in the Cachoeira River Estuary by Weather Monitoring Program (PROCLIMA)

\begin{tabular}{|c|c|c|c|c|c|c|c|c|c|c|c|c|}
\hline \multicolumn{13}{|c|}{ monthly precipitation average $(\mathrm{mm}) \pm$ standard deviation } \\
\hline & 1999 & 2000 & 2001 & 2002 & 2003 & 2004 & 2005 & 2006 & 2007 & 2008 & 2009 & 2010 \\
\hline January & $3.2 \pm 6.2$ & $4.1 \pm 6.1$ & $2.5 \pm 3.3$ & $10.5 \pm 14.7$ & $1.2 \pm 2.5$ & $4.3 \pm 4.4$ & $5.4 \pm 12.4$ & $4.1 \pm 4.4$ & $4.1 \pm 10.8$ & $3.3 \pm 7.7$ & $3.8 \pm 5.8$ & $2.9 \pm 3.6$ \\
\hline February & $5.1 \pm 6.6$ & $5.9 \pm 8.1$ & $1.9 \pm 2.7$ & $7.2 \pm 20.2$ & $3.3 \pm 1.9$ & $5.1 \pm 5.1$ & $7.8 \pm 10.4$ & $1.2 \pm 5.1$ & $1.2 \pm 14.9$ & $4.1 \pm 4.9$ & $4.3 \pm 5.9$ & $4.9 \pm 6.2$ \\
\hline March & $4.5 \pm 7.2$ & $9.1 \pm 9.6$ & $5.5 \pm 6.3$ & $4.6 \pm 5.1$ & $5.7 \pm 5.5$ & $9.3 \pm 9.7$ & $5.4 \pm 12.7$ & $7.2 \pm 11.6$ & $7.2 \pm 4.9$ & $5.3 \pm 7.5$ & $4.6 \pm 6.6$ & $4.8 \pm 6.8$ \\
\hline April & $6.6 \pm 6.6$ & $6.3 \pm 8.3$ & $3.8 \pm 3.7$ & $4.2 \pm 4.7$ & $4.4 \pm 3.8$ & $6.1 \pm 6.6$ & $8.1 \pm 6.4$ & $6.1 \pm 5.2$ & $6.1 \pm 9.5$ & $3.0 \pm 4.6$ & $8.0 \pm 16.3$ & $5.8 \pm 9.9$ \\
\hline May & $5.6 \pm 9.1$ & $2.9 \pm 4.8$ & $4.1 \pm 5.4$ & $2.8 \pm 3.7$ & $7.9 \pm 4.1$ & $2.1 \pm 2.1$ & $8.2 \pm 8.4$ & $1.7 \pm 5.6$ & $1.7 \pm 9.4$ & $1.0 \pm 2.5$ & $1.5 \pm 3.3$ & $2.7 \pm 3.2$ \\
\hline June & $5.0 \pm 9.6$ & $3.1 \pm 4.6$ & $5.4 \pm 6.9$ & $4.1 \pm 4.3$ & $3.8 \pm 5.4$ & $3.6 \pm 3.3$ & $6.9 \pm 7.1$ & $3.3 \pm 3.1$ & $3.3 \pm 4.3$ & $5.6 \pm 7.1$ & $2.7 \pm 5.4$ & $1.1 \pm 2.7$ \\
\hline July & $7.7 \pm 11.2$ & $4.9 \pm 8.6$ & $3.7 \pm 3.1$ & $4.7 \pm 5.6$ & $4.9 \pm 3.7$ & $4.3 \pm 4.1$ & $2.7 \pm 3.7$ & $1.4 \pm 3.5$ & $1.4 \pm 12.5$ & $3.3 \pm 6.8$ & $4.8 \pm 8.5$ & $7.4 \pm 8.2$ \\
\hline August & $4.8 \pm 6.9$ & $3.1 \pm 7.1$ & $4.3 \pm 5.3$ & $4.8 \pm 4.8$ & $4.7 \pm 4.3$ & $3.4 \pm 3.1$ & $4.3 \pm 2.7$ & $1.8 \pm 5.1$ & $1.8 \pm 3.5$ & $2.4 \pm 3.7$ & $5.3 \pm 13.1$ & $2.6 \pm 3.2$ \\
\hline September & $3.2 \pm 3.5$ & $3.8 \pm 6.2$ & $2.1 \pm 5.2$ & $4.3 \pm 7.7$ & $2.2 \pm 2.1$ & $3.1 \pm 3.2$ & $3.1 \pm 4.1$ & $2.6 \pm 0.9$ & $2.6 \pm 7.8$ & $1.1 \pm 1.6$ & $2.2 \pm 3.4$ & $2.4 \pm 3.1$ \\
\hline Octuber & $3.7 \pm 6.8$ & $1.5 \pm 2.9$ & $6.5 \pm 11.1$ & $1.8 \pm 3.2$ & $2.1 \pm 6.5$ & $1.1 \pm 1.7$ & $2.1 \pm 2.9$ & $7.1 \pm 6.1$ & $7.1 \pm 8.1$ & $2.0 \pm 4.1$ & $6.9 \pm 13.9$ & $3.1 \pm 6.1$ \\
\hline November & $5.9 \pm 8.1$ & $3.4 \pm 4.5$ & $1.8 \pm 4.2$ & $3.2 \pm 8.1$ & $2.2 \pm 1.8$ & $3.9 \pm 3.4$ & $8.6 \pm 13.4$ & $4.4 \pm 10.1$ & $4.4 \pm 7.8$ & $3.9 \pm 7.7$ & $2.4 \pm 4.5$ & $4.1 \pm 5.9$ \\
\hline December & $7.4 \pm 12.1$ & $6.8 \pm 12.5$ & $7.4 \pm 15.1$ & $5.9 \pm 12.1$ & $1.8 \pm 7.4$ & $6.1 \pm 6.6$ & $4.5 \pm 5.7$ & $6.7 \pm 3.7$ & $6.7 \pm 5.1$ & $7.1 \pm 12.4$ & $1.3 \pm 3.9$ & $3.9 \pm 8.1$ \\
\hline
\end{tabular}

